Joan C. Bevan MD FRCA

\title{
Congenital syndromes in paediatric anaesthesia: what is important to know
}

\section{Summary and objectives}

The purpose of this review is to re-evaluate our approach to the perioperative management of children with congenital syndromes, as a result of recent advances in the understanding of the role of genetic factors in the aetiology of specific syndrome complexes, and in accordance with current paediatric anaesthetic practice. Recent information elucidating the genetic basis of these syndromes will be examined and made relevant to paediatric anaesthetists in their emerging roles as perioperative physicians. Diagnostic testing and family counseling, as well as alterations in reactions to drugs will be considered. Finally, the current year of clinical practice at this hospital will be reviewed to determine the frequency that congenital syndromes are encountered, the most common clinical challenges they present, and to provide examples of the management of anaesthesia in selected cases. The review aims to facilitate the anaesthetist's preoperative assessment of a child with a congenital syndrome, suggest approaches to clinical anaesthetic management, and be a basis for further study of the influence of genetics in anaesthesia.

\section{Congenital syndromes}

The use of the term "syndromes" originated in the 5th century BC, when Hippocrates combined the Greek "syn, " meaning "together" with "dromos" or "course." By the 17th century "syndrome" was regarded as synonymous with "disease ${ }^{\boldsymbol{D}}$ and only acquired its present definition of "a group of symptoms which occur together and may involve a number of organs," as recently as the 19th century. At this time, physicians attached their names to syndromes, resulting in several disorders sharing the same eponym. Confusion in nomenclature led to attempts at the classification of these multiple abnormalities, errors of metabolism, genetic anomalies and complex disorders. However, associations such as "tuberculosis-malaria syndrome" and descriptions like "headache syndrome" continued to be used to describe various conditions which produced a common symptomatology. The concepts used to identify asyndromes" have also evolved through corresponding periods of change in medical emphasis, embracing clinical descriptions, histopathology, biochemistry, metabolic disorders and, most recently, genetics.

Today, the use of syndrome remains useful to describe the concurrence of specific clusters of symptoms and signs, or the phenotypic manifestations of some genetic disorders. There are now almost 3,000 named medical syndromes recorded, generating 95,000 references in the last twenty years of the MEDLARS database, with 1,000 new references appearing each month. Recently published textbooks provide resources to identify these clinical syndromes. ${ }^{1-5}$

\section{The human genome}

As a result of the ongoing worldwide Human Genome Project, coordinated by the Department of Energy and the National Institute of Health, the structure of human DNA (deoxyribonucleic acid) is being analysed and the location of the estimated 100,000 human genes is being mapped on chromosomes. In the five years since the inception of the project, almost 4,000 genes have been mapped to the 23 sets of chromosomes which make up the full complement of genetic material in human cells. Eventually, it is anticipated that 2,000 genes will be identified on each chromosome. This information will be the source for biomedical science in the future. Its anticipated benefits in medicine include the understanding and treatment of over 4,000 genetic diseases and major illnesses with multifactorial aetiology (heart disease, hypertension and diabetes) in which a genetic predisposition is important. Consequently, the role that genetic factors play in the aetiology of the pathologic processes which give rise to clinical syndromes is now better understood. Genetic diseases can be diagnosed more precisely and often prenatally, better family counseling is possible because the inheritance of syndromes can be explained beyond autosomal domi- 
nant and recessive characteristics and sporadic mutations, and there are promising innovative treatments of diseases: all of which will improve the health of the affected population.

\section{Social impact of genetic disorders}

Genetic diseases and anomalies place a burden on society which begins in childhood and continues throughout life. ${ }^{6}$ Estimates of risk show that $8 \%$ of the population under 25 years old have specific genetic diseases or anomalies and $5 \%$ of adults over 25 years have chromosomal abnormalities which influence their likelihood of developing cancer, heart disease and diabetes. Lethal chromosomal abnormalities are present in over $5 \%$ of foetuses and are a leading cause of infant mortality. They are responsible for half of the total spontaneous abortions and $6 \%$ of stillbirths and neonatal deaths. In adults, $10 \%$ of hospital admissions are related to genetic diseases, while they

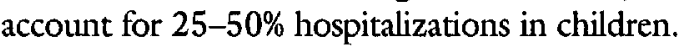

\section{Heredity and anaesthesia}

Anaesthesia and genetics have evolved simultaneously, with the first use of ether in 1846 closely followed in 1858 by the publication of Darwin's book, "Origin of the Species." Seven years later Mendel postulated his simple patterns of inheritance showing that a single gene mutant produces dominant and recessive characteristics in man. The pivotal discovery of the double helix structure of DNA by Watson and Crick in 1953 coincided with the introduction of succinylcholine and Kalow's recognition, in 1957, that plasmacholinesterase ( $\mathrm{pChE}$ ) variants were inherited as an autosomal recessive trait. Shortly after, in 1960, Denborough described malignant hyperthermia (a potentially fatal succinylcholine-induced hypermetabolic crisis), which is now known to have a multifactorial dominant inheritance in susceptible individuals. Thus, pharmacogenetics, or the abnormal reaction to drugs, became the natural link between anaesthesia and genetics. In pharmacogenetic conditions there are no phenotypical manifestations of abnormalities, and patients are asymptomatic until exposure to the provocative drugs.

The biosynthesis of plasmacholinesterase is controlled by one gene locus located on the long arm of chromosome 3 at q26. As well as succinylcholine and mivacurium, cocaine, aspirin, heroin and procaine depend on pChE for their metabolism and deficiency of this enzyme may be associated with life-threatening reactions to these drugs. Prolonged apnoea following succinylcholine or mivacurium can now be investigated or predicted by screening of pChE with molecular biological techniques. Using the polymerase chain reaction, Gabriel $e t$ al. ${ }^{7}$ characterised the $\mathrm{pChE}$ in 17 patients who exhibited pro- longed neuromuscular blockade as homozygous abnormal mutation (AA) in 10, four were heterozygous (AU or $\mathrm{AX}$ ) and three were $\mathrm{UU}$ (usual). Similarly, individual vulnerability to organophosphate insecticide poisoning and the lethal effects of the nerve gas, sarin, are also genetically controlled. Early attempts to link malignant hyperthermia susceptibility (MHS) and $\mathrm{pChE}$ variants suggested an increased incidence of the fluoride-resistant gene in patients with a history of MHS. ${ }^{8}$ As yet, no genetic linkage between the two conditions has been established. Malignant hyperthermia susceptibility was localised to the ryanodine receptor gene on chromosome 19 in $1990,{ }^{9}$ making the prospects good for a diagnostic test for MHS using molecular genetic techniques. ${ }^{10}$

Modes of inheritance of congenital syndromes may follow a single gene Mendelian pattern with autosomal dominant (Huntingdon athetosis, porphyria, Marfan syndrome) or recessive (sickle cell anaemia, Tay Sach disease, cystic fibrosis) characteristics. In these cases, the gene defect can be deduced from the family history. Dominant traits appear in every generation of a family and equally in both sexes, but isolated new mutations may arise (achondroplasia), often in association with advanced paternal age. Recessive conditions may miss generations and carriers may be partially affected clinically. One quarter of the offspring of parents who are both carriers will produce a phenotypically affected child, suggesting the possibility of consanguinity.

Sex-linked conditions (Duchenne muscular dystrophy, fragile X mental retardation, in males) can be recessive or dominant and pass through the female carrier line. Recessive traits are usually only expressed in the hemizygous affected male, while dominant traits affects female offspring of affected parents of both sexes. Unlike autosomal dominant conditions, there is no father-son transmission of sex-linked conditions. Mutations arising in mitochondrial DNA can cause rare genetic defects (Kearns Sayre disease, Lobber optic atrophy). Furthermore, genetic and non-genetic factors may interact so that the mode of inheritance becomes multifactorial (Parkinsonism).

\section{Control of gene expression}

The full genome, the source of individuality, is present in all trillion body cells of each of the world's 5-6 billion people. Each has its unique DNA which provides the genetic control to about 100,000 different body proteins, modifying phenotypes to produce the rich diversity of the population which embraces all races, life's successes and failures, the musical or the athletic. The normal human karyotype consists of 23 pairs of chromosomes: 22 homologous pairs of autosomes and 1 pair of sex chromosomes (normal female chromosome, XX, 
and male, XY). The nomenclature used for the formula for karyotypes (the complement of the chromosome) describes the number of chromosomes and the sex chromosome constitution (normal female: $46, \mathrm{XX}$ and normal male: $46, \mathrm{XY}$ ). Numerical abnormalities are indicated by $\mathrm{a}+$ or - sign e.g., $45, \mathrm{X}$ ( 45 chromosomes with only one $\mathrm{X}$ chromosome), 47,XY, +21 (47 chromosomes, $\mathrm{XY}$ sex chromosomes, and an extra chromosome 21 - trisomy 21). Structurally altered chromosomes have a system of symbols to identify the positions of the changes: frequently used symbols include $p$ or $q$ (short or long arm of chromosome), del (deletion), $t$ (translocation), pat or mat,(derived from father or mother). Thus, for example, $46, \mathrm{XX},-13,+\mathrm{t}(13 \mathrm{q} 2 \mathrm{lq})$ indicates a female karyotype with 46 chromosomes and an unbalanced Robertsonian translocation between chromosomes 13 and 21. Genetic imprinting, depending on whether the inheritance of identical defective genes is of maternal or paternal origin, can cause very different syndromes (e.g., Prader-Willi and Angelman phenotypes result from the identical defect at chromosome 15, inherited from the father or mother, respectively).

Molecular mechanisms which are responsible for normal development and maturation are regulated genetically, and their failure may be the basis for conditions such as congenital myaesthenia gravis. In mouse experiments, the acetylcholine receptor subunit $(\mathrm{AChR})$ normally switches from the foetal $(\gamma)$ to adult $(\epsilon)$ type at two to three weeks after birth. Genetically mutated "knockout" mice, in which this switch does not occur, develop normally for the first few weeks of life and then can be distinguished from their litter mates by a "whispering voice," rapid loss of muscle strength and death before three months. They exhibit similar responses to tetanic stimulation as myaesthenic patients and an abnormal sensitivity to d-tubocurarine. ${ }^{11}$

\section{Chromosomal abnormalities}

Children with dysmorphic features may be suspected of having chromosomal abnormalities. However, the same phenotypical appearance, as in Down or Turner syndromes may result from different underlying genetic causes. Some common defects, such as cleft palate and dwarfism, have multiple causes and appear as part of many recognizable syndromes. Abnormalities in chromosomes may be a) numerical (with the addition or loss of one, or occasionally, two chromosomes: aneuploidy, or the addition of a complete haploid set of chromosomes: polyploidy) b) structural (rearrangements of genetic material within or between chromosomes: balanced with no change in the amount of genetic material, or unbalanced with some gain or loss) c) or other types of defects: structural gaps, breaks, rearrangements, deletions and translocations ${ }^{6}$ (Table I).

Dysmorphology may be classified as a "syndrome when several, embryologically distinct abnormalities appear together, as in achondroplasia, Down and Marfan syndromes. Use of the term ${ }^{\text {sequence }}{ }^{\nu}$ is confined to conditions in which all abnormalities arise from a single embryological defect, such as Klippel-Feil "syndrome." Physical deformities may also arise independently of genetic influences. "Malformation" is the result of internal forces and adeformation" is applied to conditions, such as Potter's sequence, caused by external forces. Consequently, not all dysmorphism or congenital abnormalities will be ascribed to any genetic defect. However, the identification of underlying chromosomal abnormalities in an increasing number of congenital syndromes is rapidly altering the management and treatment of affected children and their families. A recently published book addresses the impact of genetic factors on anaesthesia, and provides an introduction to genetics for anaesthetists as well as describing selected syndromes of interest. ${ }^{12}$

Clinical problems associated with congenital syndromes: 12-month survey of caseload

A prospective 12-month survey (1996-7) of elective surgical cases was carried out at this tertiary care paediatric centre to identify those children who had a preoperative diagnosis of a congenital syndrome recorded on the operating room schedule. This revealed 202 children with congenital syndromes out of a total workload of approximately 9,000 cases per year $(2.2 \%$ or 1 in 45 cases). The most common congenital syndrome was Down syndrome, with 51 children affected, representing one quarter of the total. This compared with 102 children (1.1\% or 1 in 88 cases) scheduled for adenotonsillectomy, who had a clinical diagnosis of obstructive sleep apnoea syndrome, which may have a genetic basis in some cases.

Children were scheduled for surgery to correct congenital defects or for incidental surgery, often conservative dental reparations. Despite multiple actiologies, and the development of sequelae and related complications, these congenital syndromes present a limited number of anaesthetic problems. The major anaesthetic challenges, potentially associated with the conditions found in the survey, could be classified as shown in Table II. The two main anaesthetic problems were distributed amongst various types of congenital syndromes:

a) POTENTIAL DIFFICULT TRACHEAL INTUBATION: Apert (4), Charge (2), Conradi (1), Dandy-Walker (1), Down (51), Dutch-Kentucky (1), Goldenhar (3), Guérin-Stern (6), Hurler (1), Klippel-Feil (1), Marfan (1), Nager (2), Noonan (2), Opitz-Frias (1), Pierre Robin (5), Prader-Willi (2), Pyle (1), Robinow achon- 
droplasia (3), Smith-Lemmle (1), Treacher Collins (1) Turner (1), Velocardiofacial (2), William (3)

b) POTENTIAL CARDIAC COMPLICATIONS: Apert (4), Charge (2), Conradi (1), Down (51), Duchenne/ other muscular dystrophy (13), Ebstein (1), Fallot (5), Goldenhar (3), Guérin-Stern (6), Holt-Oram (1), Hurler (1), Kawasaki (2), Klippel-Feil (1), Marfan (1), Pierre Robin (5), Prader-Willi (2), Rendu-OslerWeber (1), Rett (3), Rubinstein-Taybi (2), SturgeWeber (5), Treacher-Collins (1), Turner (1), Vater (3), Von Recklinghausen (4), Velocardiofacial (2), William (3), Wiskott-Aldrich (1), Wolf-Parkinson-White (4)

\section{Clinical anaesthetic management}

Charts of thirty of the patients with some of the more common congenital syndromes were selected and reviewed retrospectively for details of anaesthetic management. This revealed the use of a wide variety of agents and techniques by individual anaesthetists, in keeping with current practices in the unit: recently introduced agents, propofol, sevoflurane, rocuronium and mivacurium were as evident as any of the more established drugs. From these records, a composite example case has been compiled, using three children with Down syndrome to illustrate the problems for the anaesthetist

TABLE I Types of chromosome abnormalities and resultant congenital syndromes in the phenotype

\begin{tabular}{|c|c|c|c|}
\hline Type of abnormality & $\begin{array}{l}\text { Genetic defect } \\
\text { in karyotype }\end{array}$ & $\begin{array}{l}\text { Congenital syndromes } \\
\text { in phenotype }\end{array}$ & $\begin{array}{l}\text { Associated features } \\
\text { and risks }\end{array}$ \\
\hline \multirow[t]{5}{*}{ Numerical } & $\begin{array}{l}\text { Trisomy } \\
\text { Can be lethal in foetus }\end{array}$ & $\begin{array}{l}\text { Autosomal: Trisomy } 13,18,21 \\
\text { Sex: Klinefelter }(47, \mathrm{XXY})\end{array}$ & $\begin{array}{l}\text { Related to maternal age. } \\
\text { All have cardiac anomalies, some } \\
\text { omphalocoeles or facial defects }\end{array}$ \\
\hline & Monosomy & $\begin{array}{l}\text { Autosomal: Lethal in foetus } \\
\text { Sex: Turner }(45, \mathrm{X})\end{array}$ & $\begin{array}{l}\text { Recurrence risk not increased by } \\
\text { age or previous experience }\end{array}$ \\
\hline & Mosaic aneuploidy & $\begin{array}{l}\text { Autosomal: Trisomy } 8,13,21 \\
\text { Sex: Turner }\end{array}$ & No increased recurrence risk \\
\hline & Uniparental disomy & $\begin{array}{l}\text { Autosomal: Deletion at chromosome } \\
15 \text {, Prader } \\
\text { Willi (father), Angelman (mother) }\end{array}$ & $\begin{array}{l}\text { Differential expression if defect } \\
\text { comes from mother or father - } \\
\text { genomic imprinting }\end{array}$ \\
\hline & Polyploidy & $\begin{array}{l}\text { Autosomal: Lethal in foetus in lst, } \\
\text { 2nd or 3rd trimester }\end{array}$ & No increased recurrence risk \\
\hline \multirow[t]{6}{*}{ Structural } & Deletions and microdeletions & $\begin{array}{l}\text { Cri du chat }(5 p) \\
\text { Wolf-Hirschorn (4p) } \\
\text { Prader Willi (15) } \\
\text { Miller-Dieker (17) } \\
\text { Di George (22) }\end{array}$ & $\begin{array}{l}\text { Recurrence unlikely unless parent } \\
\text { has rearrangements. Test parental } \\
\text { karyotypes before counseling }\end{array}$ \\
\hline & Duplications & Trisomics & Recurrence risk not high \\
\hline & Isochromosomes & $\begin{array}{l}\text { Prader Willi } \\
\text { Turner }\left(\mathrm{XX}_{\mathrm{q}}\right) \\
\text { Lethal in foetus }\end{array}$ & $\begin{array}{l}\text { Very high risk of recurrence, almost } \\
100 \% . \text { Test parental karyotypes } \\
\text { before counseling }\end{array}$ \\
\hline & Inversions & $\begin{array}{l}\text { Normal carriers } \\
\text { Stillbirths }\end{array}$ & $\begin{array}{l}\text { Recurrence in } 1-10 \% \text {. Test family } \\
\text { before counseling }\end{array}$ \\
\hline & Robertsonian translocations & Familial Down (14q2lq) & $\begin{array}{l}\text { Very rare. In mothers }<35 \text { yr. } \\
\text { recurrence risk } 2 \% \text { (father), } \\
10 \% \text { (mother). Test parents }\end{array}$ \\
\hline & Reciprocal translocations & Pregnancy loss & $\begin{array}{l}40 \% \text { risk of recurrence. Test parents } \\
\text { before counseling. }\end{array}$ \\
\hline \multirow[t]{3}{*}{ Other } & Chromosome fragile sites & $\begin{array}{l}\text { Fragile X mental retardation (Xq27.3) } \\
\text { Clinical effects depend on site }\end{array}$ & $\begin{array}{l}100 \text { fragile sites known, trait } \\
\text { according to location. Inherited }\end{array}$ \\
\hline & Marker chromosomes & $\begin{array}{l}\text { Fanconi anaemia } \\
\text { Bloom syndrome }\end{array}$ & Inherited \\
\hline & Chromosome breakage & Ataxia telangiectasia & $\begin{array}{l}\text { Random visible lesions appear in } \\
\text { metaphase, lead to structural } \\
\text { deletions and translocations }\end{array}$ \\
\hline
\end{tabular}


which this common congenital syndrome may present. Of particular note, is the general laxity of ligaments in these children and potential for cervical instability. This has been the subject of a number of case reports of serious complications, ${ }^{13}$ reviews of the predictors of cervical instability ${ }^{14-17}$ and audits of current approaches to anaesthetic management. ${ }^{18,19}$ These considerations were paramount in the following illustrative case.

This three-year-old girl with Down syndrome was scheduled for dental surgery. Her mother was 28 years old when she was born and there were two normal older brothers, A cardiac defect was diagnosed at birth, and she had elective ASD and mitral valve repair at 3 months old. At this time she was in congestive heart failure and failing to thrive. Following cardiopulmonary bypass surgery she had a high pulmonary artery pressure and required three days of nitric oxide. She also required blood pressure support transiently with epinephrine and several days of dopamine therapy. Echocardiogram on the second postoperative day

TABLE II Cumulated anaesthetic problems suspected in the paediatric surgical population with congenital syndromes surveyed over a

\begin{tabular}{|c|c|c|c|}
\hline \multirow[b]{2}{*}{ Problem } & \multirow[b]{2}{*}{$n$} & \multicolumn{2}{|c|}{ Potential anaestbetic problems in 12-mth period } \\
\hline & & Clinical Manifestations & Anaestbetic Considerations \\
\hline Cardiac instability & 129 & $\begin{array}{l}\text { Cardiac anomalies presenting for major } \\
\text { corrective surgery or subsequent } \\
\text { incidental procedures, often dental }\end{array}$ & $\begin{array}{l}\text { Preoperative cardiology assessment } \\
\text { Antibiotic prophylaxis }\end{array}$ \\
\hline $\begin{array}{l}\text { Difficult tracheal } \\
\text { intubation }\end{array}$ & 96 & $\begin{array}{l}\text { Facial deformities due to } 1 \text { st and } 2 \text { nd arch } \\
\text { defects obstruct the upper airway and require } \\
\text { surgical correction in neonates. } \\
\text { Generalized skeletal and muscular disorders } \\
\text { also produce dysmorphism or soft tissue } \\
\text { distortion of the airway. }\end{array}$ & $\begin{array}{l}\text { Preoperative assessment of airway } \\
\text { Difficult airway algorithm for management } \\
\text { Availability of emergency equipment to manage } \\
\text { airway obstruction (c.g., LMA, fibrcoptic } \\
\text { intubation, tracheostomy) }\end{array}$ \\
\hline Mental retardation & 80 & $\begin{array}{l}\text { Present to a variable degree in many congenital } \\
\text { syndromes }\end{array}$ & $\begin{array}{l}\text { Cooperation unlikely, facilitate induction by parental } \\
\text { presence or premedicant sedation }\end{array}$ \\
\hline Skeletal deformities & 51 & $\begin{array}{l}\text { Progressive bony involvement leads to } \\
\text { kyphoscoliosis and cervical lesions which } \\
\text { compromise the upper airway and } \\
\text { predispose to cardio-respiratory failure. } \\
\text { Common in myopthies and dwarfism }\end{array}$ & $\begin{array}{l}\text { Severity of scoliosis curvature } \\
\text { Respiratory function tests } \\
\text { Postoperative respiratory support } \\
\text { Intraoperative blood conservation measures } \\
\text { Postoperative pain management }\end{array}$ \\
\hline Respiratory failure & 38 & $\begin{array}{l}\text { Develops as neuromuscular and skeletal } \\
\text { conditions progress, or due to pulmonary } \\
\text { aspiration and repeated lung infections in } \\
\text { gastrointestinal lesions }\end{array}$ & $\begin{array}{l}\text { Chest x-ray } \\
\text { Respiratory function tests } \\
\text { Physiotherapy, antibiotics, bronchodilators as } \\
\text { indicated pre and postoperatively }\end{array}$ \\
\hline Metabolic & 23 & $\begin{array}{l}\text { Usually primary defect which leads to typical } \\
\text { syndrome signs and symptoms: renal, } \\
\text { hepatic osteogenesis, diabetes } \\
\text { phenylketonuria. Organ dysfunction secondary } \\
\text { to cardio-respiratory disease }\end{array}$ & $\begin{array}{l}\text { Medical consultation if necessary } \\
\text { Hepatic and renal function tests } \\
\text { Select anaesthetic drugs which are independent of } \\
\text { hepatorenal excretion for metabolism }\end{array}$ \\
\hline $\begin{array}{l}\text { Hacmopoietic or } \\
\text { vascular }\end{array}$ & 19 & $\begin{array}{l}\text { Cause blood dyscrasias or vascular anomalies } \\
\text { with lesions of variable severity depending } \\
\text { on site in body affected }\end{array}$ & $\begin{array}{l}\text { Preoperative assessment of lesions and severity - } \\
\text { hacmatology consultation and radiological } \\
\text { investigations as necessary }\end{array}$ \\
\hline $\begin{array}{l}\text { Neuromuscular } \\
\text { system }\end{array}$ & 19 & $\begin{array}{l}\text { Mostly myopathies with predisposition to } \\
\text { sudden cardiac arrest, sensitivity to } \\
\text { muscle relaxants }\end{array}$ & $\begin{array}{l}\text { Sensitive to nondepolarising muscle relaxants } \\
\text { (myaesthenia) } \\
\text { Cardiac arrest with succinylcholine } \\
\text { (Duchenne type dystrophies) } \\
\text { Mctabolic problems (mitochondrial myopathies) }\end{array}$ \\
\hline $\begin{array}{l}\text { Central nervous } \\
\text { system degeneration }\end{array}$ & 13 & $\begin{array}{l}\text { Rare and unrelenting conditions which } \\
\text { produce neurological symptoms and generalised } \\
\text { bodily dysfunction depending on site } \\
\text { of lesions }\end{array}$ & $\begin{array}{l}\text { Epileptiform seizures - check medication } \\
\text { (e.g., resistance to nondepolarising muscle } \\
\text { relaxants with phenothiazines) }\end{array}$ \\
\hline
\end{tabular}


showed poor stroke volume in the left ventricle and tricuspid and pulmonary regurgitation. Sternal closure was performed on the fifth day postoperatively and she received a course of vancomycin and cefotoxamine for suspected sepsis. Following surgery, she made fairly good progress and her cardiovascular state was stable. She had repeated upper respiratory infections and a chronic cough.

On arrival at the day-care surgical unit, she was noted to have trisomy 21 with its characteristic dysmorphic features. She had developmental delay, weighed $13 \mathrm{~kg}$, was short in stature and hypotonic. Her face was typical with slanting eyes and large tongue, and her skin was dry. Limbs showed brachdactyly and simian creases on the palms. Chart review showed that previous general anaesthesia for her $3 \mathrm{hr}$ cardiac surgery consisted of intravenous ketamine induction followed by pancuronium to facilitate nasotracheal intubation, which presented no problems. Maintenance was with oxygen enriched air and isoflurane, with fentanyl supplements. Cardiopulmonary bypass was uneventful and she was transferred to the intensive care unit for postoperative ventilation with the sternum open. Subsequently, for chest closure, the trachea was already intubated on arrival in the operating room. Vecuronium and fentanyl were given as the main anaesthetic agents during surgery and dopamine was needed over the 90 min procedure.

Essential features on examination indicated possible airway problems because the tongue was large and tonsils were hypertrophied. Her mother said that she had been told that the child's neck was "unstable," although there was a full range of neck movement. She also volunteered that "Sometimes she stops breathing during the night and has to be woken up" but there had not been any investigations for sleep apnoea syndrome. A recent "cold" had finished a week before but the child was apyrexial and the chest was clear to auscultation, with no wheezing detected. She was assessed as ASA physical status 3. Preanaesthetic considerations in the management of this case relate to:

a) Assessment of cardiac risk and review of current status, antibiotic prophylaxis

b) Recent upper respiratory infection and runny nose

c) Implications of cervical instability and the need for radiological investigation

d) Possible sleep apnoea and whether the tonsillar hypertrophy requires surgery

e) Suggestion of sensitivity to atropine

f) Sensitivity to narcotic analgesics g) Note that the maternal age at birth was less than 35 years and the descriptive term of Trisomy 21 may be incorrect and this Down syndrome patient may have a Robertsonian translocation.

Anaesthesia for the three hour dental procedure was managed successfully as follows:

The neck was stabilised during laryngoscopy and induction in the neutral position. Intravenous propofol, atropine, lidocaine and succinylcholine were administered and nasotracheal intubation achieved easily. Ampicillin was given after induction and isoflurane used for maintenance, with intermittent positive pressure ventilation throughout. No further muscle relaxants or narcotic analgesics were given and the dental surgeon injected local anaesthesia into the teeth for extractions. Postoperatively, good oxygenation was maintained and there was no respiratory compromise during recovery. The mother was not present for induction, but was brought into the recovery room as soon as the child began to wake up. The patient was discharged home later the same day as surgery and plans made to follow up the family for genetic counselling.

\section{Conclusion}

In this review, principles for the management of anaesthesia for children with congenital syndromes have been outlined, with little reference to specific drugs or techniques. Thus, newer drugs or approaches, which may not yet appear in case reports or in the older literature on the syndromes, may be considered appropriate according to the clinical experience of the anaesthetist who has an understanding of the problems created by the presence of an individual syndrome. Genetics is relevant in the emerging emphasis on the role of anaesthetists as perioperative physicians. However, the future is in the drug response variability and pain response aspects.

\section{References}

1 Katz J, Steward DJ. Anesthesia and Uncommon Pediatric Diseases. Philadelphia: WB Saunders Co., 1987.

2 Magalini SI, Magalini SC, de Francisci G. Dictionary of Medical Syndromes, 3rd ed. Philadelphia: JB Lippincott Co., 1990.

3 Jablonski S. Jablonski's Dictionary of Syndromes and Eponymic Diseases, 2nd ed. Malabar, Florida: Krieger Publishing Co., 1991.

4 Thoene JG, Smith DC (Eds). Physicians' Guide to Rare Diseases. Montvale, NJ: Dowden Publishing Co. Inc., 1992.

5 Steward DJ. Anesthetic implications of syndromes and unusual disorders. In: Steward DJ. Manual of Pediatric 
Anesthesia, 4th ed., New York: Churchill Livingstone Inc., 1995; appendix I: 434-93.

6 Friedman JM, Dill FJ, Hayden MR, McGillivray BC. National Medical Series for Independent Study: Genetics,. 2nd ed. Baltimore: Williams and Wilkins, 1995.

7 Gabriel I, Dbonneur G, Mesguish M, Amselem S, Duvaldestin $P$. Screening of pseudocholinesterase by molecular biology. Eur J Anaesthesiol 1997; 14 (Suppl 16): 31 .

8 Whittaker $M$, Britten JJ. Malignant hyperthermia and the fluoride-resistant gene. Br J Anaesth 1981; 53: 241-4.

9 MacLennan DH, Duff C, Zorzato $F$, et al. Ryanodine receptor gene is a candidate for predisposition to malignant hyperthermia. Nature 1990; 343: 559-61.

10 Levitt RC. Prospects for the diagnosis of malignant hyperthermia susceptibility using molecular genetic approaches. Anesthesiology 1992; 76: 1039-48.

11 Witzemann V. Fetal and adult type acetylcholine receptors: their role in neuromuscular signal transmission. Proceedings: 6th International Neuromuscular Meeting, Paris 1997: 1-15.

12 Weinberg GL. Genetics in Anesthesiology: Syndromes and Science. Boston: Butterworth-Heinemann, 1996.

13 Powell JF, Woodcock T, Luscombe FE. Atlanto-axial subluxation in Down's syndrome. Anaesthesia 1990; 45: 1049-51.

14 Tredwell SJ, Newman DE, Lockitch G. Instability of the upper cervical spine in Down Syndrome J Paediatr Orthop 1990; 10: 602-6.

15 Selby KA, Newton RW, Gupta S, Hunt L. Clinical predictors and radiological reliability in atlantoaxial subluxation in Down's syndrome. Arch Dis Child 1991; 66: 876-8.

16 DeLeon SY, Ilbawi MN, Egel RT, et al. Perioperative spinal canal narrowing in patients with Down's syndrome. Ann Thorac Surg 1991; 52: 1325-8.

17 Pueschel SM, Moon AC, Scola FH. Computerized tomography in persons with Down syndrome and atlantoaxial instability. Spine 1992; 17: 735-7.

18 Litman RS, Zerngast BA, Perkins FM. Preoperative evaluation of the cervical spine in children with Trisomy-21: results of a questionnaire study. Paediatr Anaesth $1995 ; 5: 355-61$.

19 Mitchell V, Howard R, Facer E. Down's syndrome and anaesthesia. Paediatr Anaesth 1995; 5: 379-84. 


\section{Syndrome congénitaux et anesthésie pédiatrique: ce qu'il faut savoir}

Joan C. Bevan, MD, FRCA

\begin{abstract}
Résumé et objectifs
Le but de cette revue est de réévaluer notre approche quant à la prise en charge périopératoire des enfants atteints de syndromes congénitaux, à la lumière des progrès récents dans la compréhension du rôle des facteurs génétiques dans la génèse des différents syndromes et en accord avec la pratique anesthésique pédiatrique courante. L'information récente concernant la base génétique de ces syndromes sera examinée et présentée de façon pertinente aux anesthésistes pédiatriques pour leur permettre de remplir un rôle en voie de développement, celui de médecin périopératoire. On présentera aussi le dépistage et les conseils génétiques aux familles, de même que les réactions particulières aux médicament. Enfin, on reverra la pratique clinique dans notre hôpital durant la dernière année pour déterminer la fréquence de survenue des syndromes congénitaux en pratique anesthésique, quels défis ils entraînent le plus fréquemment et pour fournir des exemples de conduite anesthésique dans certains cas. Cette revue a pour but de faciliter l'évaluation préopératoire par l'anesthésiste d'un enfant présentant un syndrome congénital, de suggérer des balises pour la conduite anesthésique et de constituer une base pour des études plus poussées quant à l'influence de la génétique en anesthésie.
\end{abstract}

\section{Syndromes congénitaux}

L'utilisation du terme "syndrome» date du $5^{e}$ siècle av. J.-C. lorsque Hippocrate a combiné les mots grecs «syn», signifiant «avec», avec «dromos», signifiant «le cours". Au $17^{\mathrm{e}}$ siècle, "syndrome» était synonyme de "maladio» et n'a acquis sa signification actuelle "d'un groupe de symptômes survenant ensemble et pouvant impliquer plusieurs organes" qu'au $19^{c}$ siècle. À cette époque, les médecins ont lié leur nom à des syndromes avec la résultante que plusieurs maladies portaient le même nom. Cette confusion dans la nomenclature a conduit à des essais de classification de ces anomalies multiples, erreurs du métabolisme, anomalies génétiques et désordres complexes. Cependant des associations telles «le syndrome malaria-tuberculose» et des descriptions telles «le syndrome de la céphalée» continuent à être utilisées pour décrire des conditions diverses qui produisent une symptomatologie commune. Les concepts utilisés pour identifier des «syndromes" ont aussi évolués selon l'emphase médicale des diverses périodes, passant des descriptions cliniques à l'histopathologie, à la biochimie, aux désordres métaboliques et plus récemment à la génétique. De nos jours, l'utilisation de "syndrome» demeure utile pour décrire le regroupement particulier de signes et symptômes, ou les manifestations phénotypiques d'un désordre génétique. On compte actuellement près de 3000 syndromes médicaux bien identifiés, ayant produit 95,000 entrées durant les 20 dernières années de la base de données MEDLARS, auxquelles viennent s'ajouter à chaque mois 1000 nouvelles entrées. Récemment, des livres de référence nous fournissent les instruments pour identifier ces syndromes cliniques ${ }^{1-5}$

\section{Le génome humain}

Comme résultats du Projet du Génome Humain en cours à l'échelle mondiale, coordonné par le Department of Energy et le National Institute of Health des États-Unis, la structure de l'ADN humain (acide désoxyribonucléique) est analysée et la localisation des 100,000 gènes humains identifiée sur les chromosomes. Depuis le début du projet il y a 5 ans, près de 4000 gènes ont été localisés sur les 23 paires de chromosomes qui représentent l'ensemble du matériel génétique des cellules humaines. Éventuellement, on prévoit que 2000 gènes vont être identifiés sur chaque chromosome. Cette information sera la source de la science biomédicale du futur. Ses retombées en médecine incluent la compréhension et le traitement de plus de $\mathbf{4 0 0 0}$ maladies génétiques et autres maladies majeures ( $\mathrm{g} g$ HTA, diabète, maladie cardiaque) dont l'étiologie est multifactorielle mais où la prédisposition génétique est importante. Par conséquence, on comprend maintenant mieux le rôle des facteurs génétiques dans l'étiologie des processus pathologiques entrainant des syndromes cliniques. On peut diagnostiquer plus précisément les maladies génétiques, et souvent de façon anténatale; les conseils génétiques aux familles sont possibles parce que le mode d'acquisition des syndromes peut être expliqué plus précisément que par leurs caractéristiques auto- 
somes dominantes ou récessives ou par des mutations sporadiques; il y a aussi des traitements innovateurs prometteurs pour plusieurs maladies: tous ces éléments sont de nature à améliorer la santé des populations affectées.

\section{Impact social des désordres génétiques}

Les maladies et anomalies génétiques posent une charge sur la société qui débute à la naissance et se continue toute la vie ${ }^{6}$. Les estimés montrent que $8 \%$ de la population de moins de 25 ans est porteuse de maladie ou d'anomalie génétique spécifique et que $5 \%$ des adultes de plus de 25 ans ont des anomalies chromosomiques qui influencent leurs chances de développer un cancer, une maladie cardiaque, un diabète. Des anomalies chromosomiques léthales sont présentes chez plus de $5 \%$ des foetus et sont une cause majeure de mortalité du nournisson. Ces anomalies sont responsables de la moitié des avortements spontanés et de $6 \%$ des morts-nés et des décès en période néonatale. Chez les adultes, les maladies génétiques sont reliées à $10 \%$ des admissions hospitalières alors qu'elles représentent $25-50 \%$ des hospitalisations chez les enfants.

\section{Hérédité et anesthésie}

L'anesthésie et la génétique se sont développées simultanément, la première utilisation de l'éther en 1846 étant suivie de près en 1858 par la publication de l'ouvrage de Darwin, "L'origine des espèces». Sept ans plus tard, Mendel a postulé les modalités simples de transmission génétique, démontrant que des mutations d'un seul gène affectent la transmission de caractères chez l'homme selon un mode dominant ou récessif. La découverte fondamentale en 1953 par Watson et Crick de la structure en double hélice du DNA a coïncidé avec l'introduction de la succinylcholine et la reconnaissance par Kalow en 1957 que les variantes de la pseudocholinestérase ( $\mathrm{pChE}$ ) étaient transmises sur un mode autosome récessif. Peu après, en 1960, Denborough décrivait l'hyperthermie maligne (une crise hypermétabolique potentiellement fatale déclenchée par la succinylcholine), que l'on sait maintenant être transmise selon un modèle autosome dominant multifactoriel chez les individus susceptibles. Ainsi, la pharmacogénétique, ou science des réactions anormales aux médicaments, devint le lien naturel entre l'anesthésie et la génétique. Dans les situations pharmacogénétiques, il n'y a aucune manifestation phénotypique d'anomalies et les patients demeurent asymptomatiques jusqu'à l'exposition aux médicaments déclenchants.

La biosynthèse de la pseudocholinestérase est contrôlée par un locus génétique situé sur le grand bras du chromosome 3 au site q26. Autant que la succinyl- choline et le mivacurium, la cocaïne, l'aspirine, l'héroïne et la procaïne dépendent de la $\mathrm{pChE}$ pour leur métabolisme et un défaut de ces enzyme peut entraîner, face à ces médicaments, des réactions graves mettant la vie en danger. L'apnée prolongée suite à la succinylcholine ou au mivacurium peut maintenant être prédite ou investiguée en analysant la pChE avec des techniques de biologie moléculaire. Utilisant la réaction de polymérase en chaîne, Gabriel $e t a l^{7}$ ont identifié la pChE chez 17 patients, ayant présenté un bloc neuromusculaire prolongé, comme étant une mutation anormale homozygote (AA) chez 10 , une hétérozygotie (AU ou $\mathrm{AX}$ ) chez 4 alors que 3 étaient UU (usuel). De même, la susceptibilité individuelle à l'empoisonnement aux insecticides organophosphorés et les effets léthaux du gaz neurotoxique sarin sont aussi génétiquement contrôlés. Les essais précoces pour relier la susceptibilité à l'hyperthermie maligne (SHM) et les variantes de la pChE ont suggéré que les patients avec une histoire de SHM avaient une incidence accrue du gène résistant au fluorure ${ }^{8}$. Cependant, jusqu'à maintenant, aucun lien génétique n'a été établi entre les deux conditions. La susceptibilité à l'hyperthermie maligne a été localisée en 1990 sur le chromosome 19, au gène du récepteur ryanodine $^{9}$, ce qui augure bien en ce qui concerne un test diagnostique pour la SHM qui utiliserait des techniques de génétique moléculaire ${ }^{10}$.

Les modes d'acquisition des syndromes congénitaux peuvent suivre un pattern mendélien faisant appel à un seul gène avec caractéristiques autosomes dominantes (athétose de Huntington, porphyrie, Marfan) ou récessives (anémie falciforme, maladie de Tay Sach, mucoviscidose). Dans ces cas, le défaut génétique peut être déduit de l'histoire familiale. Les traits dominants apparaissent dans chaque génération d'une famille, de façon égale dans les deux sexes, mais de nouvelles mutations isolées peuvent se présenter (achondroplasie), souvent en association avec un âge paternel avancé. Les conditions récessives peuvent sauter des générations et les porteurs peuvent n'être que partiellement affectés au plan clinique. Un enfant sur quatre de parents qui sont tous deux porteurs sera affecté cliniquement, suggérant alors la consanguinité.

Les conditions liées au sexe (dystrophie musculaire de Duchenne, retard mental chez les garçons lié au X fragile) peuvent être dominantes ou récessives et être transmises par la lignée féminine qui n'est que porteuse. Les traits récessifs ne s'expriment habituellement que chez le mâle hémizygote touché, alors que les traits dominants peuvent toucher les enfants femelles lorsque l'un ou l'autre parent est touché. Contrairement aux conditions autosomes dominantes, il n'y a pas de trans- 
mission père-fils des conditions liées aux sexe. Les mutations provenant de l'ADN mitochondrial peuvent causer de rares défauts génétiques (maladie de Kearns Sayre, atrophie optique de Leber). De plus, des facteurs génétiques et non génétiques peuvent interagir de telle sorte que le mode de transmission devient multifactoriel (maladie de Parkinson).

\section{Contrôle de l'expression génétique}

Le génome complet, la source de l'individualité, est présent dans chacune des billions de cellules du corps de chacun des 5 à 6 milliards d'habitants du globe. Chaque génome a son $A D N$ unique qui lui procure le contrôle génétique sur environ 100,000 protéines différentes, modifiant les phénotypes de façon à produire la riche diversité de population qui se compose de toutes les races, des réussites de la vie comme des échecs, des artistes comme des athlètes. Le karyotype humain normal se compose de 23 paires de chromosomes : 22 paires homologues d'autosomes et 1 paire de chromosomes sexuels (karyotype femelle XX, mâle XY). La nomenclature utilisée pour décrire les karyotypes décrit le nombre de chromosomes autosomes et le nombre de chromosomes sexuels (femelles normales : $46 \mathrm{XX}$, mâle normal: $46 \mathrm{XY}$ ). Les anomalies numériques sont indiquées par un signe + ou - vg $45, \mathrm{X}$ ( 45 chromosomes avec seulement 1 chromosome $X), 47, X Y,+21$ (47 chromosomes, chromosomes sexuels $\mathrm{XY}$ et un chromosome supplémentaire en position 21 - la trisomie 21). Les chromosomes dont la structure a été altérée sont régis par un système de symboles qui identifient les positions des changements : les symboles utilisés fréquemment sont $p$ ou $q$ (court ou long bras du chromosome), del (délétion), $t$ (transloca tion), pat ou mat (dérivé de paternel ou maternel). Ainsi, par exemple, $46, \mathrm{XX},-13,+\mathrm{T}(13 \mathrm{q} 2 \mathrm{lq})$ indique un karyotype femelle avec 46 chromosomes et une translocation Robertsonnienne non balancée entre le chromosome 13 et le 21 . L'empreinte génétique, dépendant de ce que le même défaut génétique hérité provient de la mère ou du père, peut causer des syndromes très différents ( $v g$ les phénotypes Prader-Willi et Angelman sont produits par le même défaut du chromosome 15, hérité respectivement du père ou de la mère).

Les mécanismes moléculaires qui sont responsables du développement et de la maturation normaux sont contrôlés génétiquement, et leurs défauts peuvent être la base de conditions telles la myasthénie grave congénitale. Dans les expériences chez les souris, la sousunité du récepteur à l'acéthylcholine (AchR) passe normalement du type foetal $(\gamma)$ au type adulte $(\epsilon)$ deux à trois semaines après la naissance. Des souris ayant subi des mutations génétiques et chez lesquelles ce passage du type foetal au type adulte ne se fait pas, se développent normalement pour les premières semaines de vie pour ensuite se distinguer de leurs congénères par une «voix chuchotante», une perte rapide de force musculaire et un décès avant trois mois. Elles démontrent à la stimulation tétanique une réponse analogue à celle de patients myasthéniques; elles présentent aussi une sensibilité anormale à la $d$-tubocurarine ${ }^{11}$.

\section{Anomalies chromosomiques}

On peut suspecter les enfants présentant un aspect dysmorphique d'être porteurs d'anomalies chromosomiques. Cependant un phénotype analogue à celui du syndrome de Down ou de Turner peut résulter de causes génétiques différentes. Certains défauts fréquents, comme la fente palatine ou le nanisme, ont de multiples causes et se retrouvent dans plusieurs syndromes facilement identifiables. Les anomalies des chromosomes peuvent être a) numérique (avec l'addition ou la perte de un, ou occasionnellement de deux chromosomes : l'aneuplö̈die, ou avec l'addition d'un groupe haploïde complet de chromosomes : la polyploïdie), b) structurelles (réarrangements du matériel génétique à l'intérieur ou entre les chromosomes : $b a l$ ancés, c'est-à-dire sans changement quant à la quantité du matériel génétique, ou débalancées, lorsqu'il y a gain ou perte) c) autres types de défauts : hiatus structuraux, cassures, réarrangements, délétions et translocations ${ }^{6}$ (Tableau I).

La dysmorphologie peut être classifiée comme un "syndrome» lorsque plusieurs anomalies, embryologiquement distinctes, apparaissent ensemble comme dans l'achondroplasie, le syndrome de Down ou celui de Marfan. L'utilisation du terme «séquence» est réservé aux conditions dans lesquelles toutes les anomalies proviennent d'un seul défaut embryologique, comme dans le «syndrome» de Klippel-Feil. Des déformations physiques peuvent aussi survenir indépendamment des influences génétiques. Une "malformation» est le résultat de forces internes alors que le terme "déformation» est utilisé pour des conditions, comme la séquence de Potter, causées par des forces externes. Par conséquent, on ne peut attribuer tous les dysmorphismes ou toutes les anomalies congénitales à un défaut génétique précis. Cependant, l'identification des anomalies chromosomiques sousjacentes dans un nombre croissant de syndromes congénitaux change rapidement la prise en charge et le traitement des enfants affectés ainsi que de leur famille. Un manuel publié récemment s'intéresse à l'impact des facteurs génétiques sur l'anesthésie, tout en fournissant une introduction à la génétique pour les anesthésistes et en décrivant un certain nombres de syndromes d'intérêt particulier $^{12}$. 
TABLEAU I Types d'anomalies chromosomiques et phénotypes résultants (syndromes congénitaux).

\begin{tabular}{|c|c|c|c|}
\hline Type d'anomalie & $\begin{array}{l}\text { Défaut génétique du } \\
\text { karyotype }\end{array}$ & Phénotype : syndrome congénital & $\begin{array}{l}\text { Caractéristiques associées et } \\
\text { risques }\end{array}$ \\
\hline \multirow[t]{5}{*}{ Numérique } & Trisomie & $\begin{array}{l}\text { Autosome : trisomie } 13,18,21 \\
\text { Peut être léthal chez le foetus } \\
\text { Sexuel : Klinefelter }(47, \mathrm{XXY})\end{array}$ & $\begin{array}{l}\text { Relié à l'âge maternel. Anomalies } \\
\text { cardiaques (tous), omphalocèles et } \\
\text { défauts faciaux (quelques). }\end{array}$ \\
\hline & Monosomie & $\begin{array}{l}\text { Autosome: léthal chez le foetus } \\
\text { Sexuel: Turner }(45, \mathrm{X})\end{array}$ & $\begin{array}{l}\text { Risque de récidive non accru par } \\
\text { l'âge ou une survenue antérieure. }\end{array}$ \\
\hline & Aneuploïdie en mosaique & $\begin{array}{l}\text { Autosome: trisomie } 8,13,21 \\
\text { Sexuel: Turner }\end{array}$ & Risque de récidive non accru. \\
\hline & Disomie uniparentale & $\begin{array}{l}\text { Autosome : délétion au chromosome } 15 \text {, } \\
\text { Prader- } \\
\text { Willi (père), Angelman (mère) }\end{array}$ & $\begin{array}{l}\text { Expression différente selon que le } \\
\text { défaut provient du père ou de la } \\
\text { mère - empreinte génomique. }\end{array}$ \\
\hline & Polyploïdie & $\begin{array}{l}\text { Autosome : léthal chez le foetus au } 1^{\text {cr }}, 2^{c} \text { et } \\
3^{c} \text { trimestre }\end{array}$ & Risque de récidive non accru. \\
\hline \multirow[t]{6}{*}{ Structurale } & Délétions et microdélétions & $\begin{array}{l}\text { Cri du chat (5p) } \\
\text { Wolf-Hirschorn (4p) } \\
\text { Prader-Willi (15) } \\
\text { Miller-Dieker (17) } \\
\text { Digeorge (22) }\end{array}$ & $\begin{array}{l}\text { Risque de récidive peu probable à } \\
\text { moins de réarrangements } \\
\text { chromosomiques chez un parent. } \\
\text { Vérifier les karyotypes des parents } \\
\text { avant conseils génétiques. }\end{array}$ \\
\hline & Duplications & Trisomies & Risque de récidive non élevé. \\
\hline & Isochromosomes & $\begin{array}{l}\text { Prader-Willi } \\
\text { Turner }(\mathrm{XX} \mathrm{q}) \\
\text { Léthal chez le foetus }\end{array}$ & $\begin{array}{l}\text { Risque de récidive très élevé, près } \\
\text { de } 100 \% \text {. Vérifier karyotypes des } \\
\text { parents avant conseils génétiques. }\end{array}$ \\
\hline & Inversions & $\begin{array}{l}\text { Porteurs sains } \\
\text { Morts-nés }\end{array}$ & $\begin{array}{l}\text { Récidive } 1-10 \% \text {, Vérifier la famille } \\
\text { avant conseils génétiques. }\end{array}$ \\
\hline & $\begin{array}{l}\text { Translocations } \\
\text { Robertsonniennes }\end{array}$ & Syndromes de Down familiaux (14q2lq) & $\begin{array}{l}\text { Très rares. Mères } 35 \text { ans. Risque de } \\
\text { récidive } 2 \% \text { (père) } 10 \% \text { (mère). } \\
\text { Vérifier karyotypes des parents }\end{array}$ \\
\hline & Translocations réciproques & Fausses-couches & $\begin{array}{l}\text { Risques de récidive : } 40 \% \text {. Vérifier } \\
\text { karyotypes des parent avant conseils } \\
\text { génétiques. }\end{array}$ \\
\hline \multirow[t]{3}{*}{ Autre } & Sites de chromosome fragile & $\begin{array}{l}\text { Retard mental lié au X fragile (Xq27.3) } \\
\text { Effets cliniques selon le site }\end{array}$ & $\begin{array}{l}100 \text { sites fragiles connus; } \\
\text { symptomatologie en rapport avec } \\
\text { localisation. Héréditaire. }\end{array}$ \\
\hline & Chromosomes marqueurs & $\begin{array}{l}\text { Anémie de Fanconi } \\
\text { Syndrome de Bloom }\end{array}$ & Héréditaire. \\
\hline & Bris de chromosome & Ataxie - télangiectasie & $\begin{array}{l}\text { Des lésions visibles aléatoires } \\
\text { apparaissent en métaphase, } \\
\text { conduisant à des délétions } \\
\text { structurelles et à des translocations. }\end{array}$ \\
\hline
\end{tabular}

\section{Problèmes cliniques associés aux syndromes} congénitaux : une revue de dossiers de 12 mois Une revue prospective, s'étendant sur 12 mois (1996-7), des cas chirurgicaux électifs a été réalisée dans notre centre pédiatrique tertiaire pour identifier les enfants inscrits sur la liste opératoire et présentant un diagnostic de syndrome congénital. Ceci a révélé 202 enfants sur une population totale d'environ 9000 cas par année, soit $2,2 \%$ ou 1 cas sur 45 . Le syndrome congénital le plus fréquent était celui de Down, représenté 51 fois, soit $25 \%$ du total. On peut comparer ce chiffre avec celui des 102 enfants $(1,1 \%$ ou 1 cas sur 88 ) cédulés pour adéno-amygdalectomie en relation avec un diagnostic clinique de syndrome d'apnée obstructive du sommeil, syndrome qui peut avoir une base génétique dans un certain pourcentage des cas.

Les enfants étaient cédulés pour une chirurgie correctrice des défauts congénitaux ou pour une autre chirurgie, souvent des restaurations dentaires. En dépit des étiologies multiples et du développement de complications et séquelles, ces syndromes congénitaux sont une source restreinte de problèmes anesthésiques. Les défis anesthésiques principaux, potentiellement associés aux syndromes recensés dans l'étude, peuvent être clas- 
TABLEAU II Somme des problèmes anesthésiques potentiels chez une population chirurgicale pédiatrique porteuse de syndromes congénitaux - période de 12 mois (1996-7).

\begin{tabular}{|c|c|c|c|}
\hline Problème & $N$ & Manifestations cliniques & Considérations anesthésiques \\
\hline Instabilité cardiaque & 129 & $\begin{array}{l}\text { Anomalies cardiaques se présentant pour } \\
\text { procédures correctrices majeures ou } \\
\text { pour procédures accessoires, souvent dentaires. }\end{array}$ & $\begin{array}{l}\text { Évaluation cardiologique préopératoire } \\
\text { Prophylaxie antibiotique. }\end{array}$ \\
\hline Intubation difficile & 96 & $\begin{array}{l}\text { Les déformités faciales dues à des anomalies des } \\
1^{\text {cr }} \text { et } 2^{e} \text { arcs obstruent les voies aériennes } \\
\text { supérieures et nécessitent une correction } \\
\text { chirurgicale chez le nouveau-né. }\end{array}$ & $\begin{array}{l}\text { Évaluation pré-op des voies aériennes. } \\
\text { Prise en charge selon un algorythme pour les voies } \\
\text { aériennes difficiles. } \\
\text { Disponibilité du matériel d'urgence de prise en charge } \\
\text { d'une obstruction respiratoire ( } \mathrm{g} g \mathrm{ML} \text {, firbroscopie, } \\
\text { trachéostomie). }\end{array}$ \\
\hline
\end{tabular}

Les pathologies généralisées musculaires ou squelettiques entraînent aussi du dysmorphisme et de la distorsion des tissus mous des voies aériennes.

Retard mental

Deformations squelettiques

Insuffisance respiratoire $\mathbf{3 8}$

Présence à degré variable dans plusieurs syndromes congénitaux.

51 Atteinte osseuse progressive entraîne des cyphoscoliose et des lésions cervicales qui compromettent les voies aériennes supérieures et prédisposent à l'insuffisance cardiopulmonaire. Fréquent dans les myopathies et le nanisme.

Se développe à mesure que les conditions neuromusculaires et squelettiques évoluent, ou en réponse à des aspirations avec infections pulmonaires à répétition dans les pathologies gastrointestinales.

Metabolique et symptômes typiques : rénaux, hépatiques, ostéogénétiques, diabète, phénylcétonurie. Dysfonction des organes secondaire à la maladie cardiopulmonaire.

Hématopoïrique ou

vasculaire

Système

neuromusculaire

Dyscrasies sanguines ou anomalies vasculaires avec lésions de sévérité variable dépendant du territoire affecté.

Surtout des myopathies avec prédisposition à l'arrêt cardiaque subit, sensibilité aux relaxants musculaires.

Dégénérescence du
système nerveux central
13

Conditions rares mais évoluant inexorablement et produisant des symptômes neurologiques et des dysfonctions généralisées, selon le site des lésions.
Coopération peu plausible, induction facilitée par la présence des parents ou une prémédication sédative.

Sévérité de la scoliose.

Tests de fonction pulmonaire.

Support ventilatoire postopératoire.

Mesures de conservation du sang peropératoires.

Prise en charge de la douleur postopératoire

Radiographie pulmonaire.

Tests de fonction respiratoire.

Physiothérapie, antibiotiques, bronchodilatateurs tels qu'indiqués en pré et postopératoire.

Consultation médicale si indiquée.

Tests de fonction rénale et hépatique.

Choix de médications à métabolisme indépendant

du rein et du foie.

Évaluation préopératoire des lésions et de leur sévérité. Consultation en hematologie et investigation radiologique si nécessaire.

Sensibilité aux relaxants musculaires non dépolarisant (myasthénie).

Arrêt cardiaque avec la succinylcholine

(dystrophies type Duchenne).

Problèmes métaboliques (myopathies mitochondriales).

Crises convulsives - vérifier la médication (par exemple les phénothiazines entrainent une résistance aux relaxants non dépolarisants). sifiés tel qu'indiqué à la Tableau II. On retrouvait deux problèmes anesthésiques principaux :

a) INTUBATION TRACHÉALE POTENTIELLEMENT DIFFICILE : Apert (4), Charge (2), Conradi (1), Dandy-Walker (1), Down (51), Dutch-Kennedy (1), Goldenhar (3), Guérin-Stern (6), Hurler (1), Klippel-Feil (1), Marfan (1), Nager (2), Noonan (2), Opitz-Frias (1), Pierre-Robin (5), Prader-Willi (2), Pyle (1), achondroplasic de Robinow (3), Smith-Lemmle (1), Treacher-Collins (1), Turner (1), Velocardiofacial (2), William (3). b) COMPLICATIONS CARDIAQUES POTENTIELLES : Apert (4), Charge (2), Conradi (1), Down (51), dystrophies mulculaires de Duchenne, et autres (13), Ebstein (1), Fallot (5), Goldenhar (3), Guérin-Stern (6), Holt-Oram (1), Hurler (1), Kawasaki (2), KlippelFeil (1), Marfan (1), Pierre Robin (5), Prader-Willi (2), Rendu-Osler-Weber 91), Rett (3), RubinsteinTaybi (2), Sturge-Weber (5), Treacher-Collins (1), Turner (1), Vater (3), Von Recklinghausen (4), velocardiofacial (2), William (3), Wiskott-Aldrich (1), Wolf-Parkinson-White (4). 


\section{Prise en charge anesthésique clinique}

Les dossiers de trente patients présentant quelques uns des syndromes congénitaux les plus fréquents ont été choisis et revus de façon rétrospective quant aux détails de la prise en charge anesthésique. Cette étude a révélé l'utilisation d'une grande variété d'agents et de techniques par les différents anesthésistes, selon les pratiques établies dans l'unité : les agents plus nouveaux comme le propofol, le sevoflurane, le rocuronium et le mivacurium étaient aussi bien représentés que les agents plus anciens. À partir de ces dossiers, un exemple a été composé à partir de trois patients porteurs du syndrome de Down pour illustrer les problèmes que ce syndrome congénital commun peut présenter. De façon particulière, on connaît la laxité ligamentaire de ces patients et leur potentiel d'instabilité cervicale. Ceci a fait l'objet de plusieurs rapports de cas de complications sérieuses ${ }^{13}$, de revues des éléments prédicteurs d'instabilité cervicale $^{14-17}$ et d'évaluations des approches courantes de la prise en charge anesthésique ${ }^{18,19}$. Ces considérations étaient d'importance fondamentale dans le cas suivant.

Une patiente de trois ans porteuse du syndrome de Down était cédulée pour restaurations dentaires. Sa mère était âgée de 28 ans lors de sa naissance et elle avait deux frères plus âgés. Une pathologie cardiaque a été diagnostiquée à la naissance et elle a été opérée à 3 mois pour fermeture de CIA et réparation de la valve mitrale. Au moment de la chirurgie, elle était en insuffisance cardiaque et présentait un retard staturo-pondéral significatif. En postopératoire, elle a présenté de l'hypertension pulmonaire et a reçu du NO pour trois jours; pour maintenir sa pression artérielle, elle a nécessité temporairement de l'adrénaline de même que de la dopamine pour plusieurs jours. Une échocardiographie réalisée la deuxième journée postopératoire montrait un volume d'éjection du ventricule gauche faible de même qu'une régurgitation tricuspidienne et pulmonaire. Le sternum a été fermé le cinquième jour postopératoire et elle fut traitée à la vancomycine et à la cefotaxime pour une suspicion de septicémie. Suite à la chirurgie, elle s'est significativement améliorée et son état cardiovasculaire était stable. Elle présentait des IVRS et de la toux chronique.

À son arrivée au court-séjour, on notait qu'il s'agit bien d'une trisomie 21 avec les risques caractéristiques du syndrome. Elle présentait un retard du développement, pesait $13 \mathrm{~kg}$, était de petite stature et hypotonique. Le faciès était typique avec fentes palpébrales obliques et grosse langue, et la peau était sèche. Au niveau des membres on retrouvait des doigts courts et un pli simien. La revue du dossier nous apprenait que la technique anesthésique utilisée lors de sa chirurgie cardiaque d'une durée de 3 heures avait consisté en kétamine ip suivie de pancuronium pour faciliter l'in- tubation nasotrachéale, qui avait été sans problème. Le maintien avait consisté en $\mathrm{O}_{2}$, air, isoflurane avec supplément de fentanyl. La CEC s'était déroulée sans problème et la patiente avait été transférée aux soins intensifs pour support ventilatoire, le sternum ayant été laissé ouvert. Par la suite, lors de la fermeture du sternum, elle était arrivée intubée à la salle d'opération. Les agents anesthésiques principaux avaient été le fentanyl et le vecuronium et la dopamine avait été nécessaire durant toute la procédure, d'une durée de 90 minutes.

À l'examen, les divers éléments, soit la grosse langue et les amygdales hypertrophiées, laissaient soupçonner des problèmes de maintien des voies aériennes. La mère mentionnait à ce moment qu'on lui avait dit que le cou de l'enfant était «instable», même si la mobilité cervicale était normale. Elle ajoutait aussi, de façon spontanée, que "parfois l'enfant arrêtait de respirer durant la nuit et qu'il fallait la réveiller» mais il n'y avait eu aucune investigation en relation avec un syndrome d'apnée du sommeil. Un «rhume» récent s'était terminé la semaine précédente, et l'enfant était afébrile avec une auscultation normale, sans sibillances. Son état physique était évalué comme une classe III de l'ASA. Les considérations concernant la prise en charge anesthésique de cette patiente étaient :

a) Évaluation du risque cardiaque, évaluation de l'état actuel, prophylaxie antibiotique.

b) IVRS récente, nez qui coule.

c) Implications d'une instabilité cervicale, nécessité d'une évaluation radiologique.

d) Apnée du sommeil possible; l'hypertrophie amygdalienne constitue-t-elle une indication chirurgicale?

e) Possibilité de sensibilité à l'atropine.

f) Sensibilité aux opiacés.

g) Prendre note que l'âge maternel à la naissance de l'enfant était inférieur à 35 ans et que de ce fait le terme trisomie 21 peut être inexact, ce syndrome de Down pouvant être le résultat d'une translocation Robertsonnienne.

La conduite de l'anesthésie pour la procédure dentaire d'une durée de trois heures a été la suivante : la colonne cervicale a été stabilisée en position neutre durant l'induction et la laryngoscopie. Pour l'induction, la patiente a reçu par voie iv du propofol, de l'atropine, de la lidocaïne et de la succinylcholine, et l'intubation nasotrachéale a été réalisée facilement. L'ampicilline a été administrée après l'induction. L'isoflurane a été utilisé pour le maintien avec ventilation à pression positive intermittente. La patiente n'a reçu aucun autre relaxant musculaire et aucun opiacé, 
et le dentiste a utilisé de l'anesthésie locale pour les extractions. En postopératoire, on a maintenu une bonne oxygénation et il n'y a eu aucune complication respiratoire durant le réveil. La mère n'a pas été présente à l'induction mais a été invitée à la salle de réveil dès le début du réveil de l'enfant. La patiente a reçu son congé à la maison le même jour et on a fait des plans pour suivre la famille en vue de conseils génétiques.

\section{Conclusion}

Dans cette mise à jour, les principes de conduite anesthésique pour les enfants porteurs de syndromes congénitaux ont été énoncés, avec peu d'emphase sur les médicaments et techniques spécifiques. Ainsi, les nouveaux médicaments ou les nouvelles approches, qui n'apparaissent pas encore dans les présentations de cas ou dans la littérature plus ancienne concernant les syndromes, pourront être considérés appropriés selon l'expérience clinique de l'anesthésiste, bien au fait des problèmes créés par chacun des syndromes. La génétique est très appropriée à la nouvelle vocation de l'anesthésiste comme médecin de la période périopératoire. Cependant, le futur réside dans la variabilité des réponses médicamenteuses ainsi que des réponses à la douleur.

\section{Références}

(Voir page R8) 